Received February 21, 2018

Revised June 13, 2018

Accepted June 18, 2018

\title{
An East Asian Approach to Rural Development: A Comparative of the Saemaul Undong and FELDA Programs
}

\author{
NURLIANA KAMARUDDIN*
}

The study of East Asia has generally focused on its national development experience with emphasis given to industrial urban-based growth. However, the region has also been credited for impressive rural growth due to the Northeast Asian land reform and overall investment for a Green Revolution by states. Less emphasis has been given to a comparative exploration of different rural development programs that existed. Studies on rural development programs within the region have been diverse with case-specific perspectives, rather than in accordance with a unified conceptualization of what it means to have successful rural development. This article attempts to address that gap by evaluating two cases, the South Korean Saemaul Undong and the Malaysian Federal Land Development Authority (FELDA). It applies three different development perspectives; the neoliberal approach, the developmental state approach, and the humancentered approach, to determine the degree to which these programs can be considered successful. An East Asian conceptualization of successful rural development is identified based on an emphasis on government capacity, grassroots participation, a shared mentality for national development and a prioritization on building human capital.

Keywords: East Asia, Saemaul Undong, FELDA, rural development, Malaysia, South Korea

* Senior Lecturer, University of Malaya, Kuala Lumpur, Malaysia;

E-mail: nurliana.k@um.edu.my

DOI: $10.16934 /$ isr.19.1.201806.75 


\section{INTRODUCTION}

East Asian countries, both in Northeast and Southeast Asia, have seen profound growth and the region has developed into one of the world's three core economic regions alongside North America and Europe (Dent 2016, 1). Despite the considerable differences between the Northeast and Southeast experience, studies have looked at how state-led economic development policies have achieved remarkable success for some countries in the region. The rapid rise of Japan was followed by the Newly Industrialized Countries (NICs) or 'East Asian Tigers,' which are the Republic of Korea (henceforth referred to as South Korea), Hong Kong, Singapore and Taiwan; then the 'Little Tigers' (Malaysia, Thailand, Indonesia and the Philippines), and later the socialist countries of Vietnam and China (Thompson 2004, 1082).

The emphasis on economic growth in the region has created something akin to a shared value of "catch-up mentality" with countries trying to catch up to the forerunners (Gyohten 2007, 71). It has also created a generalized perception of the East Asian development experience with emphasis given to industrial urban-based growth. However, within the studies of East Asian development, the region has also been recognized for its equitable growth that lifted a large number of the population out of poverty. This growth in rural areas has most often been credited to Northeast Asian land reform policies and overall agricultural investment for a Green Revolution by East Asian states (World Bank 2018, 19; Campos and Root 1996, 51). Less emphasis has been given to a comparative exploration of the various rural development programs that have been utilized.

Studies on rural development programs within the region have been diverse with case-specific perspectives, rather than in accordance with a unified conceptualization of what it means to have successful rural development. The few exceptions, on the other hand, have also been sub-region specific. For example, Mark Cleary and Peter Eaton (1996) looked at land tenure on the island of Borneo as a geographical entity and drew on case studies from Thailand, Malaysia, and the Philippines. Another example is Cristóbal Kay's (2002) examination of the land redistribution and agrarian reforms of South Korea and Taiwan in comparison to the Latin American experience.

Diverging approaches to rural development add to the complication of finding common ground when analyzing rural development in the region. For example, Ian Hodge and Peter Midmore (2008) presented four different general models of rural development. This included a predominantly sectoral approach focused on agriculture, a multi-sectoral approach meant to encourage diversification, a territorial approach focusing on territorial differences or a local approach directed by the local community (Hodge and Midmore 2008, 25). Although changing times and trend impact the popularity of these approaches, 
they are all still practiced in various degrees by countries around the world.

This article examines two cases, one from each sub-region, namely the Saemaul Undong of South Korea from Northeast Asia and the Federal Land Development Authority (FELDA) of Malaysia from Southeast Asia to address this gap. The Saemaul Undong and FELDA were selected to assess if there can be a unified conception of rural development as these cases are not only theoretically different in their approaches but different in their practical implementation as well. The Saemaul Undong of South Korea was a social mobilization campaign meant to encourage nationwide participation in rural development projects. Agricultural policies that were aligned with achieving a Green Revolution in South Korea were only one component of the larger program (Douglass 2014, 143).

On the other hand, the Federal Land Development Authority (FELDA) instituted in Malaysia is a large-scale land development program, aimed at creating plantation style smallholder communities by 'settling' undeveloped jungle land. FELDA was developed as an integral part of Malaysia's effort to assist the rural poor, but these rural poor were also harnessed as productive economic agents through the cultivation of cash crops to complement the national economy (Shamsul and Perera 1977, 55).

Despite these differences, both the Saemaul Undong of South Korea and FELDA of Malaysia has received significant attention for their success. The Saemaul Undong and FELDA are seen by the governments of South Korea and Malaysia as successful aspects of their respective national development effort (Han, DH 2012; Douglass 2014; MacAndrews 1979; National Archive of Malaysia 1994). Internationally, the success of the Saemaul Undong has also been acknowledged by the United Nations Development Programme and the Asian Development Bank (ADB), while the World Bank has cited FELDA as one of the most successful examples of land development programs (ADB 2012; UNDP 2014; World Bank 1978, 1992). The problem, however, is that 'success' in the study of rural development programs has mostly been a subjective endeavor. Additionally, programs that have been successful in one area can fail despite being applied in another similar community or area (Meador and Skerratt 2017, 144-145).

This article seeks to determine the degree to which the Saemaul Undong and FELDA can be considered successful through three approaches within the contemporary discourse of development: the neoliberal approach, the developmental state approach, and the human-centered approach. The neoliberal approach was selected as this has been the prevailing understanding of development in the West and employed by many international development institutes such as the World Bank and the International Monetary Fund (IMF) in shaping its development policies. In contrast, the developmental state approach is 
the dominant explanation for the experience of the East Asian countries, emerging to challenge the shortcoming in the neoliberal perspective of the region.

Both these approaches is also challenged by the human-centered approach. This approach is based on the discourse of human development, human security and human rights. It changes the referent of development from the state to the people, widening the normative expectation of development programs to focus on the provision of inclusive growth and empowerment as opposed to an emphasis on economic growth. By employing an analytical framework based on these three approaches, this study bridges the gap between theory and practice for state-led rural development programs. It can also help identify a more comprehensive overview of best practices as well as the shortcoming of rural development programs, something easily missed when assessed from only one theoretical viewpoint.

This paper employed a qualitative research approach based on document analysis. These documents include academic documents such as books and journal articles, reports from ministries and local institutions; national budgets and national development plans of South Korea and Malaysia; archived Saemaul Undong and FELDA documents; as well as news articles. What this research found is that despite different theoretical emphasis for development, an underlying commonality of the rural development efforts in East Asia can be identified, pointing to a unified approach for success. These include an emphasis on government capacity, grassroots participation, a shared mentality for national development and a prioritization on building human capital.

\section{PARADIGMS OF DEVELOPMENT}

The neoliberal approach is, for the most part, the prevailing paradigm of the west and by extension for many international development institutions such as the World Bank and the International Monetary Fund (IMF). The neoliberal approach has also been utilized to explain the success of the East Asian states, the most prominent (and controversial) of this was by the World Bank in its 1993 report The East Asian Miracle: Economic Growth and Public Policy. Although the neoliberal view has been widely criticized it remains, in practice, the frequently associated ideal for development.

Successful development from a neoliberal perspective is based on political governance that's focused on facilitating the market to drive economic growth (Jessop 2013; Dean 2014). Good governance for state practice, as introduced by the World Bank in 1989, need to be based on the preservation of private property, individual liberty, unencumbered markets and free trade through state-regulated institutional frameworks as well as an emphasis on accountability, transparency, and the rule of law (World Bank 1989, 1992b, 1994; Thomas 2001, 106; Harvey 
2007, 22). Therefore, state intervention should be limited to the provision of public and social services that would increase the people's ability to participate in a competitive market, which would ultimately lead to an increase in productivity and income in the long run.

The developmental state approach, on the other hand, has been the dominant understanding of development for East Asia. It emerged to address the shortcoming of the neoliberal explanation of the East Asian development experience. Both South Korea and Malaysia have also been strongly associated with, and even defined by, the developmental state approach (Amsden 1989; Jomo and Wee 2010). The term 'developmental state' was coined by Chalmers Johnson $(1982,18-19)$ to describe the distinctive developmental function of the state in its economic affairs.

For the developmental state approach, the onus of successful development lies in the state and its institutions. This approach is led by a 'plan-rational state' with substantive social and economic goals coupled with an effective bureaucracy that is both embedded and autonomous (Johnson 1982; Evans 1995). The state also actively governs the market, playing an active role in directing investments, cultivating industries and enacting policies as opposed to serving a regulatory function as preferred by the neoliberal approach (Wade 1990). Economic growth and productivity is the focus, but social services and equity are also prioritized for the state to retain legitimacy and support.

Finally, the human-centered approach based on the discourse of human rights, human development, and human security has continued to expand how development is viewed globally. From this point of view, focusing merely on economic growth is problematic as this growth trajectory would lack a focus on well-being (the economy is a means, not an end), economic welfare (good growth versus bad growth) and sustainability (acknowledgment of the physical limits to growth) (Bleys 2012, 356). This approach changes the referent of development from the state to the people and has increasingly become the norm when discussing development (Fukuda-Parr 2011:126).

More importantly, it expands on the understanding of what constitutes successful development programs to focus on provisions of inclusive growth and empowerment over a utilitarian emphasis on economic growth. From a human-centered perspective of development, success means a better integration of economic and social policies that would mainstream human development goals (well-being, longevity, and knowledge), with human security concerns (protection and empowerment) as well as an overall respect for human rights and entitlements (UNDP 1990; Annan 2005; UN 2009). This means not only providing for the aggregate growth but explicitly including groups that are generally disenfranchised and neglected. 


\section{SAEMAUL UNDONG AND FELDA COMPARATIVE}

The Saemaul Undong and FELDA demonstrate the considerable capacity of the South Korean and Malaysian governments in harnessing their respective rural communities into the national development efforts. Nonetheless, the national development priorities in South Korea and Malaysia had been different. Therefore, the selection of the South Korean Saemaul Undong and Malaysian FELDA as case studies is significant as the development contexts that these two countries experienced which generated the need for a state-led rural development program were different.

For South Korea, President Park Chung Hee saw economic development as an urgent national imperative as economic development would be the means of South Korea asserting its autonomy as well as achieving an independent economy and an independent defense (Kim, HA and Sorensen 2011, 19). Malaysia's experience with ethnic animosity and economic disparity along racial lines prompted the government to instill economic policies meant to foster growth and increase the economic capacity of the Malaya majority and natives known colloquially as bumiputera (sons of the soil) (Chin 2015, 399).

Consequently, the Saemaul Undong and FELDA were also guided, and limited, by these national development priorities. The Saemaul Undong was geared towards enhancing the rural economy to bridge the rural-urban gap and provide the necessary food security for continued industrialization (Park, SY 2009, 115; Han, DH 2014, 72). FELDA was utilized to provide the predominantly rural Malay poor with land as a means of economic production and then later to balance between the commercial interest of FELDA and its settler communities (Shamsul and Perera 1977; Sutton and Buang 1995; Buang et al. 2011). Despite these differing facets, the Saemaul Undong and FELDA were still guided by the strong intervention of the ruling regime as part of the national development effort of both South Korea and Malaysia respectively.

\section{The Saemaul Undong}

The period of the Saemaul Undong as a state-led rural development program lasted throughout the 1970s and established under the military rule of President Park Chung Hee. In 1970 President Park announced the need for a "new village remodeling movement" espousing the virtues of "self-help, diligence and cooperation" (ADB 2012, 5-6). The South Korean government through the Ministry of Home Affairs utilized state agencies to create bottom-up rural community participation through top-down state intervention. Under the directive of the President, a Saemaul Central Promotional Council was created and managed the "hierarchy of the administration network," which planned, 
controlled, supported, coordinated, and supervised the implementation of the Saemaul Undong nationwide (Choe, YB 1985, 1; Do, Nguyen, and Vu 2016, 107).

The Saemaul Undong encouraged active nationwide participation of the villagers by incorporating the village development council in its governance structure. Importance was placed on the villages and village leaders as agents for rural change. Saemaul village leaders were volunteers or appointed by the villagers themselves (Chung, KJ 2009; Kim, JK and Kim, KS 2013). Women and youth were also required to participate in the village development council. The women leaders head the activities of the Women's Association and were also responsible for assisting the women in the villages to organize and manage their time between domestic and village work (Choi, IY 2013, 42-49).

Overall, the objectives of the Saemaul Undong can be summarized into; 1) Income increase, which would include narrowing the income gap between urban and rural residents, 2) Improving the living environment of the farmers, 3) Mindset and attitude change (Ministry of Home Affairs [1974] 2015, 5; Park, SY 2009, 116). The Saemaul Undong grew to become more than just a rural development program. It became symbolic of the larger nation-building movement and the association of anything with Saemaul Undong became synonymous with 'development'.

The South Korean government established an extensive incentive system to ensure participation not only from the villagers but from government agencies and local public officials as well. Public officers were specifically designated for each village to oversee village level projects and these government bureaucrats, both national and local, were evaluated and promoted based on the scope of their participation and level of effort (Han, SM 2004, 75). The government also utilized an ideological approach aimed at achieving a 'spiritual revolution' in addition to increasing participation. This was done by encouraging competition amongst villages and intense nationwide promotion and campaigns.

The government classified 33,267 villages nationwide into three categories after a national survey in 1972; baseline villages, self-help villages, and independent villages. Villages would be able to advance in classification after fulfilling specific development requirements (Choe, YB 1985, 25-26; Baek, Kim, PS, and Lee, SC 2012, 419). This generated competition amongst the South Korean villages and by 1977 there were no more villages categorized as baseline villages (So, JK and Kim, SH 2010, 20; Chung, KJ 2009, 44). Overall, the Saemaul Undong brought about the large-scale improvement of villages and agricultural infrastructure. Nationwide promotion and leadership training was also carried out to provide 'spiritual training' and change the people's attitude towards development (Han, SM 2004, 74; Han, DH 2012, 11)

Another accomplishment of the Saemaul Undong was the increase of 
village income. This was mainly done through the cultivation of a new rice strain and the implementation of a dual price system, a fertilize grant as well as a reward incentive for production (Kim, CY 2011). Various income projects were also established at the village, as well as regional and national levels. These which included village infrastructure projects, saving reinvestment program, greenhouse farming, a national reforestation and nursery program, and the Saemaul Factory program (ADB 2012b; Seo et al. 2013; Lee, KJ 2013). Average rural income was comparative to the growth of urban income throughout the 1970s, sometimes even exceeding the average income of urban areas (Ministry of Home Affairs, 1978, 1980).

However, the South Korean countryside also faced continued problems despite the Saemaul Undong, or sometimes because if it. This included the continued hollowing out of the rural areas due to falling birth rate and outmigration, as well as high rates of rural debt due to the cost of renovation and smaller land holdings that lacked the ability to benefit from marketable surplus (Choe 1985; Boyer and Ahn 1991; Park, JH 1998; Mulyadi 2002). The Saemaul Undong as a state-led rural development program came to an end with the assassination of President Park in 1979 (ADB 2012, 8).

\section{FELDA}

FELDA was established in 1956 to utilize the untapped land of the Malayan peninsula by clearing out jungle areas and establishing settlements for the relocation of the rural poor. Settlements are generally 4000 to 5000 acres in size and the land, made up of residential areas and plantation areas, were divided amongst the 'settlers' who were selected by the government (Mohd Zufri et al. 2016, 108). These settlements would include plantation land as well as residential areas that were distributed accordingly to participating settlers. The settlers would then be responsible for working the land and repaying the cost of development. Once the cost has been repaid, land ownership would be transferred from the state government to the settler on a 99-year lease basis (FELDA 2013, 9).

Unlike the authoritarian political structure of South Korea during the implementation of the Saemaul Undong, Malaysia has had a competitive civilian democracy since its independence. It also has a clear separation of power between the federal and state government although the federal government dominates the governance of the country (Loh 2015). A centralized federal agency was meant to prevent the conflict caused by the distribution of decision-making power. In order to coordinate the administration for all the settlements, state governments were required to grant FELDA full administrative rights over settlement areas (Rizalman 2015, 18).

By creating plantation style settlements for smallholders, FELDA sought 
to 1) overcome the issue of unemployment and under-utilization of labor in the rural areas, 2) overcome the problem of uneconomical land ownership and division, 3) increase the income of rural communities 4) increase the living standards of rural communities and 5) establish progressive and disciplined rural communities that are positive towards development (Asan Ali et al. 1999, 1). Over the years, FELDA's governance structure changed in accordance with the political-economic climate of the country. However, even when change has been motivated by concerns of economic efficiency, it eventually became dominated and influenced by the ruling coalition.

From independence to 1990, FELDA's main priority was land development and resettlement and was placed under the administration of the Ministry of Land and Regional Development (Ministry of Land and Regional Development 1982). FELDA settlements were an 'all-inclusive' development package. Settlers were provided with a substantial amount of agriculture land and a collective housing in the village area where these new rural communities could derive acceptable levels of incomes to ensure reasonable levels of well-being (Asan Ali et al. 1999, 13). Settlers were also provided with training and support services to manage their plantation (Shamsul and Lee 2006).

The FELDA settlements focused on the production of rubber followed by oil palm from the 1960s, and on a smaller scale, sugar cane and cocoa on some plantations (Shamsul and Perera 1977; Abazue et al. 2015). During this period FELDA created a new settlement-based administrative unit through the establishment of a Scheme Development Committee known as the Jawatankuasa Kemajuan Rancangan (JKKR) (FELDA 1979). Every settlement's JKKR was made up of the settlement manager who functioned as the Chair and the appointed settlers' development officer as the secretary.

Other members of the JKKR would also include the chair of the settlement's school board, the chair of the settlement's cooperative, the Women's Organization (Gerakan Persatuan Wanita GPW) chair and the Youth Association chair. Three other members would also be appointed based on the reference of the Settlement Manager. Regional and national level JKKR were also established in 1995 in order to include the settlers in the decision-making process (National Archive of Malaysia 1994, 14-15).

From 1990 to 2001 FELDA underwent a transition from a land development agency to commercial plantation development. During this period FELDA stopped taking in settlers and the corporate ownership structure was also formalized in 1995 with the formation of FELDA Holdings Berhad. The changing governance structure is also reflected in the changing dynamics of ownership over FELDA as the Ministry of Finance owned 49 percent of the shares while 51 percent was owned by the settlers through the settler's cooperative, the Koperasi Permodalan FELDA (KPF) (Aliyu Salisu and Ismail 
2016, 426). Some settlements have also completed the repayment of the initial development cost for the settlement and choose to leave the FELDA administration. In those cases, the JKKR is reorganized as the JKKK Jawatankuasa Kemajuan Kampung or Village Development Committee.

Since 2001, FELDA has consolidated and expanded its role in agribusiness. The changing priority and structure of FELDA meant that the implementation of rural development efforts under FELDA also began to face conflicting goals. On one hand it is meant to be an agency to address rural poverty, but on the other hand, it is concerned with generating profit as a company (Mehmet 1988, 63). This has been even more apparent with the corporatization of FELDA and the involvement of politics in its administration.

In 2001, then Prime Minister Mahathir established direct political business linkage with FELDA when he shifted the administration of FELDA from the government bureaucracy closer to UMNO's control (Rokiah 2010, 49). The role of FELDA chairman has been held by an UMNO affiliated politician instead of a government bureaucrat since 2001 and in 2004 FELDA was also moved from the Ministry of National and Rural Development to the Prime Minister's Department, bringing it even closer into the federal government's administrative fold (Shamsul and Lee 2006, 21; Khor 2014, 90).

Since the beginning of the 21st century, FELDA's focus shifted towards the empowerment and capacity building for the second and third generation of FELDA settlers. As a result, FELDA has begun to incorporate new measures to diversify the income streams for its settlers as the younger generation began to veer away from agriculture. FELDA provided educational opportunities through financial aid like scholarship and loans as well as employment training (Zulkifli et al. 2014). FELDA also initiated programs to encourage different entrepreneurship initiatives. These included a National Food Storage initiative, an Entrepreneurship Incentive Scheme, and a One Region One Industry program (Shamsul and Lee 2006; FELDA 2014; Zulkifli et al. 2014).

Besides the production and sale of oil palm and rubber, FELDA as a company has also diversified its interests into other businesses such as manufacturing, hospitality, and properties. In 2007, FELDA divested its commercial arm into a separate entity, FELDA Global Venture (FGV) and in 2012 FGV was listed as a publicly traded corporation (Rizalman 2015). FELDA as a business corporation was also competitive in the private sector as a major palm oil producer. This also meant dealing with international challenges concerning the production of palm oil such as environmental issues and sustainable development of the commodity. FELDA became a member of the Roundtable on Sustainable Palm Oil (RSPO), a non-profit organization established in 2004 aimed at developing and implementing "global standards for sustainable palm oil” (Abazue et al. 2015, 483; RSPO 2016, 4). 
The Malaysian government's changing focus from providing land for the poor to creating a competitive agribusiness agency has led to a development effort based on macroeconomic gains. This approach had achieved remarkable success not only based on the number of settlements FELDA was able to establish but also on the significant rise in income for the settlers with the settlers' income remaining mostly above the national poverty line (Ragayah 2013, 46). However, the settlers' earning is dependent on the market price of commodities, agricultural practices, and farm output (FELDA 1995, 5). This resulted in a lack of income stability for settlers which FELDA would compensate with a minimum income scheme. The income supplemented to the farmers would later be deducted from future earnings when the price of commodities has risen again (Shamsul and Lee 1988, 91).

However, this also contributes to a major issue that FELDA settlers face, the issue of debt. The settlers are expected to repay their settlement cost (for land and housing) over the period of 15 years at a 6.25 percent interest rate (Khor, Saravanamuttu, and Augustin 2015, 28). Other debts that settlers would generally take on include replantation cost, renovation loans as well as socioeconomic loans (FELDA 2014, 102). A 2016 report to the Malaysian House of Representative puts the collective total of debt owed to FELDA at about RM 5 billion (Tay 2016). FELDA settlers also suffer from several other problems like an aging settler population that has become increasingly dependent on FELDA to maintain the productivity of their plantation land, as well as a continued dependency on migrant workers (Suziana and Ibrahim 2011; Saiful Bahri 2013; Khor et al. 2015).

Although FELDA has succeeded in creating productive rural settlements, increased political intervention in FELDA also led to the erosion of the agency's autonomy. Political allegiance to the United Malays National Organisation (UMNO), the party leading the National Front was also an important factor in the selection of settlers and settlement representatives (Guyot 1971; Ishak 1992; Shireen Mardziah 1998; Khor 2014). FELDA settlers are constantly reminded to 'be grateful' to the government for being selected as a FELDA settler and receiving continued benefits from the government (National Archive of Malaysia 1978; Utusan 2013). In return, FELDA settlements serve as s political stronghold for UMNO (Guyot 1971; Awang Had 1987; Khor 2014; Maznah 2015).

\section{AN EAST ASIAN UNDERSTANDING OF SUCCESSFUL RURAL DEVELOPMENT}

The following table presents a summarized overview of the programs comparing the differences in the governance structure and implementation process of the Saemaul Undong and FELDA along with the outcome of both programs. 
TABLE 1. COMPARATIVE OF SAEMAUL UNDONG AND FELDA

\begin{tabular}{|c|c|c|}
\hline & Saemaul Undong & FELDA \\
\hline \multirow{4}{*}{ Structure } & Mobilization campaign & Land Development agency \\
\hline & Empowerment of local governments & $\begin{array}{l}\text { Centralized control bypassing local state } \\
\text { governments }\end{array}$ \\
\hline & $\begin{array}{l}\text { Incorporation of endogenous village } \\
\text { development councils }\end{array}$ & $\begin{array}{l}\text { Exogenous establishment of settlement } \\
\text { development councils (JKKR) }\end{array}$ \\
\hline & Elected/voluntary village leaders & Elected/appointed settlers' representative \\
\hline \multirow{4}{*}{ Process } & Selective assistance & All inclusive 'package deal' \\
\hline & $\begin{array}{l}\text { Green revolution and income diversification } \\
\text { effort }\end{array}$ & Focus on cash crop \\
\hline & Campaign and ideological dissemination & $\begin{array}{l}\text { After 1990: } \\
\text { Income diversification }\end{array}$ \\
\hline & & $\begin{array}{l}\text { Balancing between commercial estate and } \\
\text { settlers' development }\end{array}$ \\
\hline \multirow{4}{*}{ Outcome } & $\begin{array}{l}\text { Rapid village and agricultural infrastructure } \\
\text { improvement. }\end{array}$ & $\begin{array}{l}\text { Large scale land development and } \\
\text { infrastructure provision }\end{array}$ \\
\hline & $\begin{array}{l}\text { Increased rural income, but not comparable to } \\
\text { increased living cost with increased rural debt. }\end{array}$ & $\begin{array}{l}\text { Increased rural income, but vulnerable to } \\
\text { fluctuation with long-lasting debt cycle }\end{array}$ \\
\hline & $\begin{array}{l}\text { Agriculture modernization, but lack of } \\
\text { sustainability. }\end{array}$ & $\begin{array}{l}\text { Agricultural modernization, but lack of } \\
\text { independence (significant political capture } \\
\text { and patronage) }\end{array}$ \\
\hline & $\begin{array}{l}\text { Rapid outmigration and hollowing out of } \\
\text { rural areas. }\end{array}$ & $\begin{array}{l}\text { Out-migration and aging settlers' community } \\
\text { with low employment opportunities on } \\
\text { settlements }\end{array}$ \\
\hline
\end{tabular}

Source: Compiled by Author

Both the developmental state approach and the neoliberal approach have been used to explain the success of the East Asian countries and similarly, this can be applied to the Saemaul Undong and FELDA as well. The Saemaul Undong and FELDA strongly reflect measurements of success based on the developmental state approach. However, it also does fairly well from a neoliberal perspective. Similarly, there are strength and weaknesses when evaluated from a human-centered perspective. It is important to note that just as the debate continues concerning the larger concept of an East Asian development model, this study does not claim that there is an East Asian rural development model.

Nevertheless, enough commonalities can be drawn to conclude a unified approach of successful rural development as understood in East Asia; one defined by an emphasis on government capacity, grassroots participation, a shared mentality for national development and a prioritization on building human capital. Most importantly, these commonalities overlap within the three different perspectives and present a picture that the East Asian rural development effort cannot be defined by only one perspective. 


\section{The Neoliberal Approach}

From a neoliberal approach, it can be argued that the Saemaul Undong and FELDA helped facilitate the participation of the rural communities in the market. Although the government provided subsidies and assistance for infrastructure development and education, this was not necessarily against the neoliberal recommendation as this was meant to facilitate market integration and competition. Farmers enjoyed better access to urban markets in the case of the Saemaul Undong while FELDA would pay the settlers based on the market price of their agricultural products. In both instances, the Saemaul Undong and FELDA do facilitate market competition.

What the neoliberal prescription does not recommend, however, are the interventions of the state in "financial, inputs, and outputs markets" to selectively boost production and protect the farmers (Dorward et al. 2004, 81). Conversely, if the South Korean and Malaysian government were to heed the neoliberal prescription it would have severely hampered the well-being of the farmers. In the case of South Korea, the fertilizer subsidies and the dual price policy for grains directly improved the farmers' income. For Malaysia, without FELDA's guarantee of a minimum earning, the volatility of the international market for rubber and oil palm would have also adversely affected the settlers' earning. This reinforces some of the criticism that has been levied on the neoliberal approach and the shortcoming of a market-led growth.

More importantly, markets in rural communities tend to suffer from a higher transaction cost and an urban bias in development (Khan 2000). However, the Saemaul Undong and FELDA did not merely rely on interventionist policies. Effort was also made to diversify income streams for the villagers and settlers although the overall result varied in its success. Delivering on the economic promises was one of the factors that lent to the legitimacy of the programs and encouraged the participation and support from the rural communities. The success of the Saemaul Undong and FELDA when it comes to effectiveness and efficiency is not an outcome derived from a market-led growth and this is better explained by the developmental state approach.

\section{The Developmental State Approach}

Although the bureaucracy shaped under the Saemaul Undong and FELDA was different, especially in the case of the relation of the central/federal government with the local/state governments, both programs achieved a high degree of efficiency and grassroots participation. South Korea incorporated local governments under the Saemaul banner while FELDA explicitly excluded the state governments. The structures of the village administrations were also 
different. The Saemaul Undong utilized endogenous, existing village councils, but introduced new leadership roles within these councils. FELDA shaped completely new development councils and introduced an exogenous corporate style bureaucracy in the settlements.

Despite these differences, both the Saemaul Undong and FELDA were able to produce an interesting balance of embeddedness and autonomy. In both cases, the governments embarked on what Lim Jinho terms as a process of "vertical modernity" and it developed a vertical relation in terms of state control of society, but lacked a horizontal development of "equality, equity and autonomy of civil society" and pressures civil society "to create consensus for resource mobilization to aid development" (Lim 2015, 10). The South Korean government took full advantage of the village as a natural cooperation unit while FELDA's bureaucratic restructuring created a coordinated and efficient settlement.

Both the Saemaul Undong and FELDA had clearly articulated goals that shifted to accommodate changing economic and social objectives. This helped shape the policies implemented under the Saemaul Undong and FELDA. The Saemaul Undong began with infrastructure improvement then moved on to projects meant to generate and increase rural income that was complemented with education and training initiatives. FELDA provided an 'all-inclusive' development package where the settlers would move into fully equipped and developed settlements. The emphasis on agriculture has also given way to various other programs aimed at increasing the capability and opportunities for growth especially amongst the newer generation of settlers.

\section{The Human-Centered Approach}

When evaluated from the human-centered perspective, the Saemaul Undong and FELDA also present an interesting mix of successes and shortcoming. The human-centered perspective calls for "inclusion of all in the development discourse and process" which was achieved to some degree by the Saemaul Undong and FELDA (UNDP 2016, 17). The human-centered approach has also explicitly included explicit concern gender equality and empowerment of women as evident by Goal 3 of the Millennium Development Goals (MDGs) and then Goal 5 in the Sustainable Development Goals (SDGs).

Therefore, an aspect that reveals the progressive nature of both programs was the explicit inclusion of women and youth into its administrative structure. Women were included in the decision-making process and women organizations play an important role in contributing to the well-being of the rural societies. These leadership roles in village councils and the JKKR added a dimension of empowerment for women that was not previously available to women in rural 
South Korea and Malaysia (Abdul Hamid, Rahimah and Sulong 1987, 43; Han, DH 2012, 12; Kim, JK and Kim, KS 2013, 28;). Although the education, and training that were made available improved the capacity of the women in these rural communities, much of it was still focused on the traditional reproductive roles and home management (Choi, IY 2013, pg; Gan 1995, 96; Mkandawire 2010, 71).

Women's role in economic activities during the Saemaul Undong and in FELDA were different in scope. The Saemaul Undong encouraged and increased women's participation in productive economic activities including recognizing the work put into Saemaul Undong projects equally as the men (Choi, IY 2013, 43; Chung, KJ et al. 2012, 631). However, women's labor lacked the compensation of their male counterpart and women were still required to perform household duties on top of their domestic responsibilities (Choi, IY 2013, 88-89, OECD 2016, 118).

In the case of FELDA, women were excluded from land ownership and agricultural earnings from productive land given to settlers, limiting their economic productivity in the early years. It was only much later when women's economic capacity increased as women gain land ownership through inheritance or participated actively in entrepreneurship initiatives (Scudder 1985, 177-178). In both cases, although there was an explicit effort to empower women by including them in village and settlement decision making process, the impact on economic empowerment was still questionable.

Consideration for the environment was also present in both programs. In the Saemaul Undong, the Saemaul reforestation program contributed tremendously to the successful reforestation of the country (Lee, KJ 2013). FELDA has also been an active member of the Roundtable on Sustainable Palm Oil (RSPO) since its inception in 2004. The settlers operating under FELDA receive training for environmentally sustainable practices from FELDA officers from time to time. Enforcement officers from the RSPO would also conduct regular inspections on the settlers' and FELDA's agricultural lands to ensure compliance of best practices as formulated by the organization (Abazue et al. 2015, 486).

On the other hand, grassroots empowerment was still lacking. The Village Development Councils under the Saemaul Undong were confined in the scope of their function and defined by mandated objectives from the central government. The participation of rural communities was mostly limited to the task of implementing projects, as opposed to being empowered to actively contribute to their local development. This limitation resulted in coercive implementation measures so local government officials were able to say that they achieved the goals set by the central government.

The JKKK/JKKR of FELDA suffered from similar lack of empowerment. This was made even more apparent over the years as the lack of social 
empowerment within the communities meant FELDA eventually lost its autonomy, resulting in a significant political capture. As a whole, sustainability was predicated on strong political support by the central/federal government. The Saemaul Undong was altered and eventually lost its initial mandate after the end of Park Chung Hee's regime. Similarly, FELDA's long-term sustainability is entwined with the continued dominance of UMNO as the ruling party in Malaysia. In both cases, the cost of development is passed on to the rural communities in the shape of rising rural debt.

\section{CONCLUSION}

What this study reveal is that despite significant divergence in underlying conditions, the Saemaul Undong and FELDA share similar characteristics in the measurements of success and good governance practices from the different perspectives of development, as well as weaknesses and challenges. Therefore, these shared strength and weaknesses allow this paper to identify an East Asian conceptualization of successful rural development based on an emphasis on government capacity, grassroots participation, a shared mentality for national development and a prioritization on building human capital. Similarly, the East Asian rural communities continue to face challenges of increasing debt, high rates of outmigration and an inability to remain sustainable without government support.

Based on the findings derived from the three different perspectives of development, several policy suggestions can be considered for governments and the donor community in implementing rural development programs. First, any effort for a state-led rural development program needs to consider the various stakeholders and their roles. The responsible ministry/agency should be given sufficient autonomy and be embedded in a comprehensive network which would allow them to ensure the success and sustainability of projects. A comprehensive governance network which includes members of the rural communities, NGOs and local interest group would ensure that the decision-making process is inclusive and participatory.

Secondly, development policies and reforms need to take into consideration how rural and urban areas affect each other. This includes not only complementary industries but also labor migration. Development programs need to take into consideration not only in building a self-sustaining agricultural industry but rather a diversified economic base which can generate opportunities in line with the global economy and increasing competition.

Finally, the policy formulation and institutional form of a rural development program cannot remain static. The Saemaul Undong could achieve much within the ten years because villagers were able to decide and execute 
individual projects for their own projects. On the other hand, FELDA's longevity can be attributed to its changing institutional structure and its ability to adopt to new challenges. The emphasis on agriculture was also shifted to initiate programs meant to accommodate the needs of the newer generation of settlers.

\section{Acknowledgements}

The author would like to thank the Korea Foundation ASEAN Fellowship Grant and the University of Malaya for support on the research. The author would also like to thank Dr. Brendan Howe for his extensive review of the initial dissertation work.

\section{REFERENCE}

Abazue, C. M., A. C. Er, ASA Ferdous Alam, and Halima Begum. 2015. "Oil Palm Smallholders and Its Sustainability Practices in Malaysia." Mediterranean Journal of Social Sciences 6(6 S4): 482-88.

Abdul Hamid Abdullah, Rahimah Abdul Aziz and Sulong Mohamad. 1987. "Development and Socio-cultural Changes in Rural Malaysia." Akademika 30:29-48.

Aliyu Salisu Barau and Ismail Said. 2016. "From goodwill to good deals: FELDA land resettlement scheme and the ascendancy of the landless poor in Malaysia." Land Use Policy 54: 423-431.

Amsden, Alice H.1989. Asia's Next Giant: South Korea and Late Industrialization. New York: Oxford University Press.

Annan, Kofi. 2005. In Larger Freedom: Towards Development, Security and Human Rights for All. Report of the Secretary General to the United Nations, United Nations: Geneva.

Asan Ali Golam Hassan, Mahani MohdMamat, Noor Al-Huda Abd Karim and Hassan Ali. 1999. Kemiskinan dan agihan Pendapatan di tanah Rancangan FELDA (Poverty and Income Distribution on FELDA Settlements), Sintok: Universiti Utara Malaysia.

Asian Development Bank (ADB). 2012. The Saemaul Undong Movement in the Republic of Korea: Sharing Knowledge on Community-Driven Development. Manila: Asian Development Bank.

Awang Had Salleh. 1987. "The Impact of Technological Development on the Political, Economic and Social Life in Malaysia." Analisis 1(1): 1-6.

Baek, In Rib, Pan Suk Kim and Soo Chul Lee. 2012. "Contributions and Limitations of Saemaul Undong in Korea for Regional Development and Welfare Improvement in Less Developed Countries." Public Administration and Development 32: 416-429. 
Boyer, William W. and Byong Man Ahn. 1991. Rural Development in South Korea: A Sociopolitical Analysis. Newark, DE: University of Delaware Press.

Bleys, Brent. 2012. "Beyond GDP: Classifying Alternative Measures for Progress." Social Indicators Research 109(3): 355-376.

Buang, A; A. Habibah, J. Hamzah and Y.S. Ratnawati. 2011. "The Agropolitan Way of Re-Empowering the Rural Poor." World Applied Sciences Journal 13 (Special Issue of Human Dimensions of Development: 1-6.

Campos, Jose Edgardo and Hilton L. Root. 1996. The Key to the Asian Miracle: Making Shared Growth Credible. Washington D.C.: The Brookings Institute.

Chin, James. 2015. "Malaysia: Psuedo-Democracy and the Makings of a Malay-Islamic State." In Handbook of Southeast Asian Democratization edited by William Case, 399 - 409. Abingdon and New York: Routledge.

Choe, Yang Boo.1985. "Strategies for Rural Development in Korea: The Case of Rural Saemaul Undong in the 1970s," Presented at the International Forum on Industrialization and Rural Change, September 17-26, 1985, Seoul.

Choi, Inyi. 2013. The Role of Women's Organization under the Saemaul Undong (New Village Movement) in Rural Communities. Knowledge Sharing on Korea's Development in Women's Policies, Research Paper 8-3-2, Seoul: Korean Women's Development Institute (KWDI).

Chung, Kap Jin. 2009. Research Report on Saemaul Undong: Experience and Lessons from Korea's Saemaul Undong in the 1970s. Seoul: Korea Development Institute.

Cleary, Mark and Peter Eaton. 1996. Tradition and Reform: Land Tenure and Rural Development in Southeast Asia. Kuala Lumpur: Oxford University Press.

Dean, Mitchell. 2014. "Rethinking Neoliberalism." Journal of Sociology 50(2): 150- 163.

Dent, Christopher M. 2016. East Asian Regionalism. London and New York: Routledge.

Do, Trang Thu, Hanh Thi My Nguyen, and Trang Thu Vu. 2016. “A Comparative

Study on the Self-Help Approach in Rural Development between Vietnam's New Rural Development and Korea's Saemaul Undong." Journal of East Asian Economic Integration 20(1): 91-125.

Dorward, Andrew, Jonathan Kydd, Jamie Morrison, and Ian Urey. 2004. "A Policy Agenda for Pro-Poor Agricultural Growth.” World Development 32(1): 73-89.

Douglass, Mike. 2014. "The Saemaul Undong in Historical Perspective and in the Contemporary World." In Learning from the South Korean Developmental 
Success: Effective Developmental Cooperation and Synergistic Institutions and Policies edited by Ilcheong Yi and Thandika Mkandawire, 136-171. Hampshire and New York: Palgrave Macmillan.

Evans, Peter.1995. Embedded Autonomy: States and Industrial Transformation. New Jersey: Princeton University Press.

FELDA. 1979. Kajian Pindaan Kepada Ordinan Kemajuan Tanah 1956 (Research on Amendment to the 1956 Land Development Ordinance). Archive Call Number: 1995/0034362.

FELDA. 1995. Pembangunan Tanah, Usaha dan Pencapaian (Land Development, Efforts and Achievement). Kuala Lumpur: FELDA. Archive Call Number: 2006/0030066

FELDA. 2013. Felda Pemankin Transformasi (Felda Transformation Catalyst). Kuala Lumpur: FELDA. Archive Call Number: 2013/0013048.

FELDA. 2014. Laporan Tahunan (Annual Report), FELDA, Kuala Lumpur.

Fukuda-Parr, Sakiko. 2011. "Theory and Policy in International Development: Human Development and Capability Approach and the Millennium Development Goals." International Studies Review 13(1): 122-32.

Guyot, D. 1971. "The Politics of Land: Comparative development in two states of Malaysia." Pacific Affairs 44(3): 368-389.

Gyohten, Toyoo. 2007. "The Future of Asia." In East Asian Visions: Perspectives on Economic Development, 69-81. Washington and Singapore: The World Bank and the Institute of Policy Studies.

Harvey, David. 2007. "Neoliberalism as Creative Destruction." The Annals of the American Academy of Political and Social Science 610: 22-44.

Han, Do Hyun. 2012. The Successful Cases of the Korea's Saemaul Undong (New Community Movement). 2011 Modularization of Korea's Development Experience, Seoul: KDI School of Public Policy and Management.

Han, Seung-Mi. 2004. "The New Community Movement: Park Chung Hee and the Making of State Populism in Korea." Pacific Affairs 77(1): 69-93.

Hodge, Ian and Peter Midmore. 2008. "Models of Rural Development and Approaches To Analysis Evaluation and Decision-Making." Économie Rurale 307(307): 23-38.

Ishak Shari. 1992. "Rural Development and Rural Poverty in Malaysia. The Experience During the New Economic Policy. 1971-1990.” In Poverty Amidst Plenty: Research Findings and the Gender Dimension in Malaysia edited by Jamilah Ariffin, 25-68. Petaling Jaya: Pelanduk Publication.

Jessop, Bob. 2013. "Putting Neoliberalism in Its Time and Place: A Response to the Debate." Social Anthropology/Anthropologie Sociale 21(1): 65-74.

Johnson, Chalmers. 1982. MITI and the Japanese Miracle: The Growth of Industrial Policy, 1925-1975. Stanford: Stanford University Press.

Jomo, Kwame Sundaram and Chong Hui Wee. 2010. Lessons from Post-Colonial 
Malaysian Economic Development. Working Paper No. 2010/102, Helsinki: UNU World Institute for Development Economics Research (UNU-WIDER).

Kay, Cristóbal. 2002. "Why East Asia Overtook Latin America: Agrarian Reform, Industrialisation and Development." Third World Quarterly 23(6): 1073-1102.

Khan, Mahmood Hasan. 2000. Rural Poverty in Developing Countries: Issues and Policies. IMF Working Paper, Washington D.C.: International Monetary Fund.

Khor, Yu Leng. 2014. "The Political Tussle Over Felda Land Schemes - Umno

Strengthens Its Malay Rural Fortress in 13th General Election.” Kajian Malaysia (Malaysian Research) 32(2): 89-121.

Khor, Yu Leng, Johan Saravanamuttu and Deborah Augustin. 2015. The FELDA

Case Study. HCS Report, Consulting Study 12, Oxford: LMC International Ltd.

Kim, Chung-yum. 2011. From Despair to Hope: Economic Policymaking in Korea 1945-1979. Seoul: Korea Development Institute.

Kim, Hyung-A and Clark W. Sorensen. 2011. Reassessing the Park Chung Hee Era, 1961-1979: Development, Political Thought, Democracy and Cultural Influence. Washington: University of Washington Press.

Kim, Joon-kyung and K.S. Kim. 2013. "Why the Saemaul Undong is So Important to Understanding Korea's Social and Economic Transformation." In New Research on Saemaul Undong: Lessons and Insights from Korea's Development Experience, 16-85. 2012 Modularization of Korea's Development Experience, Seoul: KDI School of Public Policy and Management.

Lee, Kyung Joon. 2013. "Saemaul Undong and Forest Rehabilitation in Korea:

Saemaul Income Boosting Project and the Role of the Village Forestry Cooperative." in New Research on Saemaul Undong: Lessons and Insights from Korea's Development Experience, 247-413. 2012 Modularization of Korea's Development Experience, Seoul: KDI School of Public Policy and Management.

Lim, Jinho. 2015. Modernity, the South Korean Path. US-Korea Institute at SAIS Working Paper Series, Washington D.C.: John Hopkins University.

Loh, Francis K. W. 2015. "Centralised Federalism in Malaysia: Is Change in the Offing?" In Routledge Handbook of Contemporary Malaysia edited by Meredith L. Weiss, 72-82. Abingdon and New York: Routledge.

MacAndrews, Colin. 1979. "The FELDA Land Schemes in Malaysia." In Group Farming in Asia: Experiences and Potential edited by John Wong, 140-152. Singapore: Singapore University Press.

Maznah Mohamad. 2015, "Fragmented but captured: Malay voters and the 
FELDA factor in GE13." In Coalitions in Collision: Malaysia's 13th General Elections edited by Johan Saravanamuttu, Lee Hock Guan, and Mohamed Nawab Mohamed Osman, 123-158. Singapore: Institute of Southeast Asian Studies.

Meador, John E. and Sarah Skerratt. 2017. "On a Unified Theory of Development: New Institutional Economics \& the Charismatic Leader." Journal of Rural Studies 53: 144-55.

Mehmet, Ozay. 1988. Development in Malaysia: Poverty, Wealth and Trusteeship, Petaling Jaya: INSAN (the Institute of Social Analysis)

Ministry of Home Affairs (내무부). 1974. "The Development of the Saemaul Movement." In 2015. The Saemaul Movement: A Sourcebook edited by Do Hyun Han and Larry L. Burmeister. 3-11. Gyeonggi-do: The Academy of Korea Studies Press.

Ministry of Home Affairs (내무부). 1978. 새마을운동 : 시작에서 오늘까지

(Saemaul Undong: From Beginning Until Today). Accessed April 6, 2016, https://www.kdevelopedia.org/Resources/all/새마을운동-0520130909 0128056.do?fldIds=TP_TER|TP_TER_NA\#.VwSGrXIf3IU.

Ministry of Home Affairs (내무부). 1980. 새마을운동 (Saemaul Undong). Accessed April 6, 2016, https://www.kdevelopedia.org/Resources/territorialdevelopment/새마을운동－05201309100128086.do?fldIds=TP_TER|TP TER_NA\#.VwSK5nlf3IU.

Ministry of Land and Regional Development (Kementerian Kemajuan Tanah dan Kemajuan Wilayah). 1982. FELDA, FELCRA, Dara, Kejora, Ketengah, Kesedar, KEDA. Kuala Lumpur: Ministry of Land and Regional Development.

Mkandawire, Thandika. 2010. "From Maladjusted States to Democratic Developmental States in Africa." In Constructing a Democratic Developmental State in South Africa: Potential and Challenges edited by Omano Edigheji, 59-81. Cape Twon: HSRC Press.

Mohd Zufri Mamat, Boon-Kwee Ng, Suzana Ariff Azizan and Lee Wei Chang. 2016. "An attempt at implementing a holistic inclusive development model: Insights from Malaysia's land settlement scheme." Asia Pacific Viewpoint 57 (1): 106-120.

Mulyadi. 2002. 'Did Saemaul Undong Increase Rural Communities' Income?: Rethinking About Saemaul Undong's Contribution and Political Motive Behind Its Initiation." (Masters Dissertation, School of Public Policy and Management, Korea Development Institute).

National Archive of Malaysia (Arkib Negara). 1978. "Felda: Koleksi Keratan Akhbar [Versi Inggeris, Melayu dan Melayu-Jawi] (FELDA Newspaper Clipping Collection [English, Malay and Jawi-Malay version])" Archive Call Number 2007/0012542. Business Times.1978. "Felda Settlers warned 
against unruly actions." August 11. Bintang Timur. 1978. "Peneroka Felda Buat Huru-Hara Kerajaan Nak Ambil Tindakan. (Government Will Take Action Against FELDA Settlers Causing Chaos)." August 11.

National Archive of Malaysia (Arkib Negara). 1994. Pengkisahan Sejarah FELDA (FELDA Historical Narrative). Archive Call Number 2006/ 0030092 .

OECD. 2016. A New Rural Development Paradigm for the $21^{\text {st }}$ Century: A Toolkit for Developing Countries. Paris: OECD Publishing.

Park, Jin Hwan. 1998. The Saemaul Movement: Korea's Approach to Rural modernization in 1970s. Jeollanam-do: Korea Rural Economic Institute.

Park, Sooyoung. 2009. "Analysis of Saemaul Undong: A Korean Rural Development Programme in The 1970s." Asia-Pacific Development Journal 16(2): 113-140.

Ragayah Mat Zin. 2013. "The New Economic Policy and Poverty Eradication in Malaysia." In The New Economic Policy in Malaysia: Affirmative Action, Ethnic Inequalities and Social Justice edited by Edmund T. Gomez and Johan Saravanamuttu, 31-60. Singapore: National University of Singapore Press.

Rizalman Kusnan. 2015. Mencorakkan Pembangunan FELDA: Mengenali Generasi FELDA (Shaping the Development of FELDA: Knowing The FELDA Generation). Kuala Lumpur: Aidy Jaya Enterprise.

Rokiah Talib.2010. Raja Muhammad Alias: Arkitek Felda (Raja Muhammad Alias: the Architect of Felda). Bangi: Penerbitan Universiti Kebangsaan Malaysia.

Roundtable on Sustainable Palm Oil (RSPO). 2016. Impact Report 2016. Accessed December 15, 2017, https://www.rspo.org/publications/download/ df716d24dd1ee80.

Saiful Bahri Kamaruddin. 2013. "Aging Settlers Poses Challenge to FELDA." UKM News Portal, published April 23, 2013, accessed September 29, 2016, http://www.ukm.my/news/arkib/index.php/extras/1412-aging-settlersposes-challenge-to-felda.html.

Scudder, Thayer. 1985. "A Sociological Framework for the Analysis of New Land Settlement." In Putting People First: Sociological Variables in Rural Development edited by Michael Cernea, 121-153. Oxford: Oxford University Press.

Seo, Hyo Duk, Sang Heon Kang, Kwang Yong Kim, Hoi Tae Kim and Sang Jo Kang. 2013. White Revolution of Agriculture in Korea: The Achievement of Year-round Production and Distribution of Horticultural Crops by the Expansion of Greenhouse Cultivation. 2012 Modularization of Korea's Development Experience, Seoul: Rural Development Administration and Korea Fruit Growers Association. 
Shamsul Bahrin and Perera P.D.A. 1977. FELDA 21 Years of Development. Kuala Lumpur: FELDA.

Shamsul Bahrin and Boon Thong Lee. 1988. FELDA: 3 Decades of Evolution. Kuala Lumpur: FELDA.

Shamsul Bahrin and Boon Thong Lee. 2006. FELDA's Fifty Years: Land Pioneers to Investors. Kuala Lumpur: FELDA

Shireen Mardziah Hashim. 1998. Income Inequality and Poverty in Malaysia. Maryland: Rowman and Littlefield Publishers.

So, Jin Kwang and Sun Hee Kim. 2010. 새마을운동을 통한 마을 공간구조 개 편 연구 (Restructuring spatial structure at village level through Saemaul Undong). Gyeonggi-do: Korea Research Institute for Human Settlements.

Sutton, Keith and Amriah Buang. 1995. "A New Role for Malaysia's FELDA: From Land Settlement Agency to Plantation Company." Geography 80(2): 125-37.

Suziana Mat Yasin and Ibrahim Ngah. 2011. A Review of the Trends and Patterns of Population Mobility in Rural Malaysia and Its Implication to the Rural Economic Development." In ICORE 2011-The 1st International Conference on Rural Development and Entrepreneurship, 407-417. Kedah: Universiti Utara Malaysia.

Tay, Chester. 2016. "Felda Settlers' Collective Debt Reached RM5b as at July 2016, Parliament Told." The Edge Market, published October 31. Retrieved December 2, 2017 (http://www.theedgemarkets.com/article/felda-settlers\%E2 $\% 80 \% 99$-collective-debt-reached-rm5b-july-2016-parliament-told).

Thomas, Caroline. 2001. "Global Governance, Development and Human Security: Exploring the Links.” Third World Quarterly 22(2): 159-175.

Thompson, Mark. R. 2004. "Pacific Asia after 'Asian Values': Authoritarianism, Democracy, and 'Good Governance."' Third World Quarterly 25(6): 1079-95.

United Nations. 2009. Human Security in Theory and Practice: An Overview of the Human Security Concept and the United Nations Trust Fund for Human Security, New York: United Nations.

United Nations Development Programme (UNDP). 1990. Human Development Report 1990: Concept and Measurement of Human Development. New York: Oxford University Press.

United Nations Development Programme (UNDP). 2015. Saemaul Initiative Towards Inclusive and Sustainable New Communities: Implementation Guidance. New York: UNDP.

United Nations Development Programme (UNDP). 2016. Human Development Report 2016: Human Development for Everyone. New York: UNDP.

Utusan. 2013. "Warga FELDA perlu bersyukur apa yang dikecapi. (FELDA Settlers Should be grateful of what has been achieved)." Utusan, 
published February 19, 2013, accessed September 29, 2016, http://ww1. utusan.com.my/utusan/Dalam_Negeri/20130219/dn_02/Warga-Felda-perl u-bersyukur-apa-yang-dikecapi.

Wade, Robert. 1990. Governing the Market: Economic Theory and the Role of Government in East Asian Industrialization. Princeton and Oxford: Princeton University Press.

World Bank. 1987. The Jengka Triangle projects in Malaysia: Impact Evaluation Report. A World Bank Operations Evaluation Study, Washington D.C.: World Bank.

World Bank. 1989. From Crisis to Sustainable Growth - Sub Saharan Africa: A Long-Term Perspective Study. Washington D.C.: World Bank.

World Bank. 1992. Malaysia - FELDA Palm Oil Mills Project. Washington D.C.: World Bank.

World Bank. 1992b. Governance and Development. Washington D.C.: World Bank.

World Bank. 1994. Development in Practise: Governance, The World Bank's Experience. Washington D.C.: World Bank.

World Bank. 2018. Riding the Wave: An East Asian Miracle for the 21st Century. World Bank East Asia and Pacific Regional Report, Washington, D.C.: World Bank.

Zulkifli Mohamad, Ruzman Md Noor, Suwaid Tapah, Johari Talib, Maharam Mamat, Wan Zulkifli Wan Hassan, Jamsari Alias and Nasruddin Yunos. 2014. "Rural Land Management in Malaysia: Referring to the Role of Federal Land Development Authority (FELDA)." Middle-East Journal of Scientific Research 22 (1): 18-25. 